\title{
RELATIVE DEPRIVATION, IDENTITY POLITICS AND THE NEO-BIAFRAN MOVEMENT IN NIGERIA: CRITICAL ISSUES OF NATION-BUILDING IN A POSTCOLONIAL AFRICAN STATE
}

\author{
Remi Chukwudi Okeke \\ Department of Public Administration and Local Government \\ University of Nigeria, Nsukka \\ remiokeke@gmail.com
}

Keywords: Relative deprivation, Identity politics, Neo-Biafra movement, Nigeria, Nation-building, Postcolonial state, African state

\begin{abstract}
This study examines the linkages between relative deprivation and identity politics in a postcolonial state. It further investigates the relationship among these variables and nationbuilding challenges in the postcolony. It is a case study of the Nigerian state in West Africa, which typically harbours the attributes of postcoloniality and indeed, large measures of relative deprivation in her sociopolitical and economic affairs. The study is also an interrogation of the neo-Biafran agitations in Nigeria. It has been attempted in the study to offer distinctive explanations over the problematique of nation-building in the postcolonial African state of Nigeria, using relative deprivation, identity politics and the neo-Biafran movement as variables. In framing the study's theoretical trajectories and in historicizing the background of the research, ample resort has been made to a significant range of qualitative secondary sources. A particularly salient position of the study is that it will actually be difficult to locate on the planet, any group of people whose subsequent generations (in perpetuity) would wear defeat on the war front, as part of their essential identity. Hence, relative deprivation was found to be more fundamental than identity politics in the neo-Biafran agitations in Nigeria. However, the compelling issues were found to squarely border on nation-building complications in the postcolony.
\end{abstract}

\section{INTRODUCTION}

Socio-political issues in many African states are characterized by the phenomenon of postcoloniality. Consequently, nation-building has remained a problematic question in many of these states. The Nigerian state typifies these nation-states where nation-building has remained a gargantuan occupation of sundry political actors. The variety of customs, languages, and traditions among Nigeria's 389 ethnic groups gives the country a cultural diversity [1]. Incidentally, this cultural diversity is among the critical issues of nation-building in this African state. Nigeria officially became independent from Britain in 1960. But by 1966, the country had become a fullblown case of ethno-cultural catastrophes, which culminated into the Nigeria-Biafra civil war. The central problematique of the Nigerian narrative is nation-building challenges. As part of this conundrum, the Biafran irritations have currently reemerged in the Nigerian state and are truly attributable to nation-building deformities. However, in December 2015, Nigeria's Minister of Information, Lai Mohammed, described the basic cause of the neo-Biafran agitations as economic [2]. The Minister said that there were actually many political frontlines in Nigeria: religious, ethnic and their likes but that these issues do not come to the fore until when there were serious economic problems (as the country was experiencing). But about the same time of the Minister's remarks, the Biafran agitators were displaying their Biafran national flags alongside Nigerian flags, at a football match between Nigeria and Algeria, at the Under-23 African Cup of Nations qualifiers holding in Dakar, the capital of Senegal. Dressed in T-shirts with the Biafra logo, the itinerant campaign group later displayed a large flag of their supposed country, calling for Biafran autonomy. They were of course, subsequently expelled from the stadium by Senegalese officials, who ordered security 
personnel to tear down the Biafran flags and posters [3]. Were the neo-Biafrans also pushed to Senegal by the same economic problem? Furthermore, a notable Nigerian political scientist has fathomably ascribed the neo-Biafran agitations to identity politics [4]. To what extent therefore, are these assessments framed on valid explications? It is against this background that this study sets out to examine the questions of relative deprivation, identity politics and the neo-Biafran movement in Nigeria.

\section{CONCEPTUAL HIGHLIGHTS}

Relative Deprivation: According to Fahey [5], the concept of relative deprivation was first used in a series of social-psychological studies of the United States' armed forces published in 1949 (under the title The American Soldier). The work was based on a large body of research [6.7] carried out by the US War Department, between 1941 and 1945 (on factors affecting motivation and morale among troops in the American army). The theory was developed to explain how discontent among the military units did not always arise directly from the objective privations they encountered but varied according to how they framed their assessments of their own circumstances. These appraisals typically were based on comparisons they made between themselves and others who might be in different situations but (who nevertheless) were somehow thought of as providing relevant reference points for self-appraisals [5]. Walker \& Pettigrew [8] explain that the initial concept of relative deprivation was simple: persons may feel deprived of some desirable thing relative to their own past, another person, persons, group, ideal, or some other social category. Consequently, relative deprivation evolved as a theoretical direction bordering on intergroup comparison that is used in explaining social phenomena - of group agitations.

Identity Politics: Kuo \& Margalit [9] have asked: What determines the identity category people feel they most belong to and what is the political significance of one's proclaimed identity? They argue that the answers to these questions are important for understanding phenomena such as policy preferences, social cleavages, and perhaps even political conflict. The term, identity in this study, denotes classification in a certain social category [9]. We acknowledge the existence of other plausible definitions of identity but what serves our purposes is the social-category classification. Furthermore, our subject matter relates more closely with the idea of group identity. We define identity politics therefore as the political activities that have to do with the projection of ones own group identities and the prevention of these identities from being subjugated by the members of the other disparate groups in the allocation and reallocation of sundry values.

Neo-Biafra Movement: The Nigeria-Biafra war of 1967-1970 was precipitated by interethnic mudslinging arising from seemingly irresoluble cultural contrasts. The original irritant actors were the post-independence politicians whom as a collectivity, were generally believed to be patently corrupt. Nigeria's three major ethnic blocs are the Hausa-Fulani, the Yorubas and the Igbos (Ibo is a corrupt [probably anglicized] form of the correct Igbo nomenclature). Subsequently, some radical elements in the Nigerian military chose to topple the civilian government through a highly bloody coup d'état in January 1966. Curiously, nearly all the coup casualties were of the HausaFulani origin in Northern Nigeria, including the country's Prime Minister, Abubakar Tafawa Balewa and the immensely influential Premier of the Northern Region of Nigeria, Sir Ahmadu Bello. In further curiosity, the military masterminds of the coup (whose radical and patriotic antecedents were unquestionable) were mainly Igbo elements, led by Chukwuma Kaduna Nzeogwu (born and bred in Northern Nigeria). The Igbo is the most peripatetic ethnic group in Nigeria [10]. Consequently, Northern Nigeria was (and is still) highly peopled by Igbos. The bloody coup d'état of January 1966, having been interpreted as an Igbo affair by the Hausa-Fulani of Northern Nigeria, led to an endless orgy of reprisal attacks in which countless numbers of Igbos were beheaded and slaughtered in Northern Nigeria. Incidentally, the most senior officer of the Nigerian Army at the time, Major General Aguiyi Ironsi, was an Igbo man. He evidently was not part of the bloody plot in January 1966. The residue of the civilian regime at that time, invariably handed over the affairs of 
the state to him and he became Nigeria's Head of State. The reprisal attacks embedded a counter coup in July 1966 in which General Ironsi was brutally murdered by Hausa-Fulani elements in the Nigerian Army.

As the pogrom-like tragedy continued in the North of Nigeria, the irreconcilable differences of the new military rulers in the country (on how to run the affairs of the state) led to the Igbodominant Eastern Region, severing relations with the rest of the new Nigerian nation-state. Lt Col. Chukwuemeka Odumegwu-Ojukwu was the Military Governor of the Eastern Region while Yakubu Gowon (subsequently General Yakubu Gowon) was the Military Head of State of Nigeria. The Eastern Region of Nigeria was renamed the Republic of Biafra by the secessionists. The remaining part of Nigeria (under Gowon) however, chose to teach the separationists a lesson or two and the Nigeria-Biafra war ensued. The war was fought between 1967 and 1970 when the Biafran rebellion was roundly defeated by Nigeria. Concisely, the neo-Biafran movement in Nigeria is a regrouping of some Nigerian Igbos, claiming to be actually Biafrans and not Nigerians. Their two principal organizations are the Movement for the Actualization of the Sovereign State of Biafra (MASSOB) and the Indigenous People of Biafra (IPOB).

Nation Building: Indeed, conceptual disputations are integral to social science scholarship. However, when we place premium on the conceptual disagreements, it reduces the value of critical empiricism in our engagement. We shall avoid such conceptual strife in this study. Lumun [11] therefore simply sees nation building as a process of bringing diverse groups together to develop their common land. Eme and Onyishi [12] further opine that nation building is synonymous with national integration. In this study, nation building stands for the process of national integration whereby spirited attempts are made by state-actors to weave previously disparate ethnic groups together, into a new national entity. In this conceptualization, there is emphasis on process. In other words, nation building is not a product purchasable by state-actors. There is additional emphasis on spirited attempts, which suggests that weak inputs to the process, invariably detracts from nation building.

Postcolonial State: The departure point in this sub-section is to state in downright terms that post-colonialism and neocolonialism are dissimilar constructs. They may be allied paradigms of engagement in the social sciences and humanities but their conceptual demarcations are definitive. In this study therefore, the focus is on postcoloniality. Under colonialism, the currently de jure independent (African) states and their sundry ethnic trajectories were brought under colonial subjugation. Neo-colonialism refers to the scenario of de jure but not de facto independent jurisdictions. Then what is postcoloniality? We highlight that colonialism created unilateral and forceful nuptial conditions among the indigenous ethnic groupings that the colonizers met on ground. When the insidious invaders departed, it became the destiny of the new state actors to manage their postcolonial heritage, inclusive of its ethnic complications. The postcolony is therefore is essentially characterized by challenges of ethnic ambiences, which give rise to other humongous difficulties. Hence, the postcolonial state in this study essentially represents that state with colonially induced ethnic combinations in state formation that have become cantankerous in interethnic relations in such states and these grouchy relations are principally responsible for the apparent or relative lack of collective human progress in such a state.

\section{CRITICAL ISSUES OF NATION-BUILDING IN POSTCOLONIAL NIGERIA: RELATIVE DEPRIVATION AND IDENTITY POLITICS}

Incendiary Episode(s) and Relevant Anecdotes: It is truly, conceptually tempting to frame a neoBiafran analysis on the political leadership strand of identity politics, whereby some aggrieved political gladiators instigate the agitations under inter-ethnic power tussles. Some otherwise eminent Nigerian scholars have constructed their viewpoints on these contentious premises [4]. On December 2, 2015, some persons believed to be pro-Biafra agitators, allegedly burnt down the central mosque in the commercial city of Onitsha, South East Nigeria and destroyed trucks believed 
to be owned by a notable Northern Nigerian businessman of the Muslim faith. It is also strongly believed that the masterminds of such actions in which lives were allegedly lost only sought to provoke inter-religious crises and thereby get Nigeria further embroiled in needless bloodletting [13]. The prevalent framing of such incendiary issues in Nigeria remains identity politics, not nation-building failures and relative deprivation. What level of credibility and utility are ascribable to such subsisting thesis of identity politics or is the evident scenario that of unconstructive identity politicization?

Sometime in July 2015, President Muhammadu Buhari was on a state visit to the United States of America [14]. This researcher (resident in the city) attended a meeting in his village at Ukpor, South-East Nigeria, preparatory to the funeral ceremony of a deceased villager. Prior to the arrival of the principal mourners, the gathered villagers were held spellbound by Okafor [15] who informed his captive audience that President Obama had summoned the Nigerian President to the White House because of the Biafran matter. The storyteller narrated that President Buhari was also billed to explain to the United Nations (General Assembly?) why the Biafran issue was still pending in Nigeria, as the UN had since granted the Biafran request but the Nigerian government had refused to implement it. In any case, he concluded to his audience, America and the United Nations had given Nigeria a deadline of December 31, 2015, to accede to the request of "Biafrans" (to go their separate way). Curiously, even when the chief mourners subsequently arrived (for the major mournful meeting to commence) the people remained more embedded in Okafor's narratives. Which powerful politician is instigating Okafor?

Additionally, on a certain date in November 2015, this researcher was entering the city of Aba in Abia State, South East Nigeria (Aba is a notable spot of neo-Biafra nationalism) and made the following encounter. The major entrance to the city (Aba-Owerri Road had been taken over by a sea of citizens in black garments, numbering nearly twenty five thousand persons. The crowd comprised youths, males, females and even the aged. They were protesting the detention of Nnamdi Kanu, the visible promoter of the pirate Radio Biafra and invariably, leader of the neo-Biafran group - the Indigenous People of Biafra (IPOB) - by the Government of Nigeria. (A prominent Nigerian civil rights activist has depicted this same character (Kanu) as Mr. Watermelon-Head [16]). It was on a working day that I saw the neo-Biafrans. The city of Aba is famous for commercial ventures and so, upon further investigation, this researcher noted that the local markets and sundry stalls in the city where all fully functional. So where did this number of people come from? A source suggested that such number of protesters were usually recruited from different states in the neo-Biafra region of the country for such parades. But the more critical issue is that written all over the faces of these neoBiafran citizens are anger and frustration, against a state (the Nigerian state) to which they should have contentedly belonged. It was easy to conclude that all the protesters were unemployed individuals. They were mainly young people. And the truth is that these youths were not necessarily clamouring for Biafra. They only need some form of positive change in their lives. Thus, the struggle for Biafra has become a metaphor for changing the material conditions of these young people [17]. The neo-Biafran issue is therefore translatable to a national, not an Igbo question [18].

To this class of citizens, the gospel according to Okafor is usually the gospel truth. Hence, the neo-Biafra movement is hoisted on such tragicomic narratives. By the way, Okafor used to reside in the city but had to return to the village, after his makeshift business place was demolished to beautify the city and make it more habitable for and agreeable to the more opportune citizens. It was not the first time that such fate had befallen him. In frustration, he returned to the village and became a neo-Biafran foot soldier. In deed, in neo-Biafran politics, no force of modern means of communication can beat the propaganda machinery of the movement's ground forces, as typified in Okafor. Thus, critically speaking, identity politics is at the center of the neo-Biafra agitations but not as masterminded by disadvantaged politicians. It must be noted that the neo-Biafrans are not terrorists. They are not also plausibly describable as insurgents. They are not articulately antigovernment. They move about with their identity cards as members of one form of neo-Biafran organization or the other. Terrorists do not engage in protest marches. Insurgents do not display 
willingness to negotiate with government as the neo-Biafrans do. The only quirky issue about these people is that they can also show you the Biafra currency (which is legal tender among them) while also making full use of the currency of the Nigerian state, to which they claim not to belong.

Further Critical Issues. According to a notable Nigerian human rights / women rights activist and politician, Hannatu Musawa, if a referendum were held today, there is no doubt that over $70 \%$ of people in the five southeast states (the home base of the neo-Biafrans) would vote YES for separation [19]. This translates to the failure of extant nation-building mechanisms in the country. The elite of the South East (Nigeria) may consider unbelievable this position of Musawa but the truth remains that in every society, the elite are in the minority. In South East Nigeria therefore, while some of the elite dismiss the neo-Biafran agitators as containable rascals, the agitators keep drawing sympathies from an ever-increasing number of the underclass. In their center-center relations, the elite of the South East give the impression to the power elite of the larger Nigerian collectivity that the neo-Biafran irritation is easily crushable. Nevertheless, something keeps making the Nigerian dream disagreeable to the underprivileged class of South East Nigeria, as represented by Okafor. It is a misrepresentation of facts to conclude that the neo-Biafran agitation is elite-sponsored - indeed sponsored by the Igbo elite.

In Why Men Rebel, Ted Robert Gurr denotes relative deprivation as that construct of divergence between what people think they deserve, and what they now think they can get [20]. In other words, the discrepancies between what people want (their value expectations) and what they actually gain (their value-accruing capabilities). Gurr argues that the intensity of relative deprivation varies strongly in terms of the average degree of perceived discrepancy between value expectation and value capabilities and that people are more likely to revolt when they lose hope of attaining their societal values. Furthermore, that the intensity of discontent or frustration varies with the severity of depression and inflation that is experienced by the people [20]. At the turn of the last century, crude oil had earned Nigeria approximately \$280 billion [21]. In addition, between 2006 and 2012 alone, 42 oil and gas companies operating in the country, paid a total of $\$ 293$ billion to the Federal Government of Nigeria, as taxes, royalty, dividends, etc [22]. Succinctly stated, Nigeria's historically huge earnings have been in these enormous measures. Despite these huge earnings however, about 110 million Nigerians (out of a population-estimate of about 180 million) are currently living below poverty line [23]. The Nigerian avaricious elite have looted the funds. Truly therefore, the Nigerian specie of the looting elite defies description [24]. Therefore, in the framing of relative deprivation in Nigeria, the ethnic trajectory must be a highly narrow conceptualization. There is also the elite dimension.

Indeed, the generic Nigerian elite seem to be imbued with a pathological incapacity to resist criminality. For instance, the Nigerian political and business elite have characteristically looted the hundreds of millions of dollars and billions of naira meant for the fight against Boko Haram terrorism in the country [25] and succeeded in crafting criminality as business deals in the nation's oil industry [26]. To add insult to injury, the neo-Biafran subaltern surveys his surroundings and concludes that the machinery and resources of the state have been used to provide more modern public amenities in the other ethnic regions than in his own abject location. Consequently, his current weltanschauung borders on relative deprivation.

It will actually be difficult to locate on the planet, any group of people whose subsequent generations (in perpetuity) would wear defeat on the war front, as part of their essential identity. In the case of Biafra, subsequent generations of the people have emerged, whose only knowledge of the Nigeria-Biafra war were obtained from books, other recordings and oral history. They were not witnesses to the war and its brutalities. On the other hand (on the Nigerian side of the war) most of the principal combatants are still wielding political influence in the Nigerian state and they happen to be on the other side of the ethnic divide. They include General Yakubu Gowon, who as Head of State was Commander-in-Chief of the Nigerian Armed Forces that defeated Biafra and General Olusegun Obasanjo, former Military Head of State and former civilian President, who has ruled Nigeria for a combined period of eight years and was indeed the man that received the surrendering 
Biafran Commanders. Others include General Muhammadu Buhari, former Military Head of State and current President of Nigeria; General Ibrahim Badamasi Babangida, Military President of Nigeria from 1985 to 1995 and General Theophilus Danjuma, former Chief of Army Staff and former Defence Minister. There are still many others. These men have remained among the principal actors in policy making in Nigeria, including the ostensible nation-building policies, from the end of the civil war in 1970 to date. It is therefore not unlikely that their public policy inputs have been bearing anti-Biafran imprimatur and signs of a victorious-army mentality. The neoBiafrans do not need elite promptings to develop acute sensitivities to such surrounding issues of relative deprivation. The consequences of all of this in Nigeria have been nation-building contradictions.

\section{CONCLUSION}

Essentially, the neo-Biafran agitations in the Nigerian state are explainable within an overall context of identity politics but it will not be correct to conclude that powerful Igbo politicians, who feel disadvantaged in the current political configurations in the country, instigate the persisting confrontations. Indeed, such conjectures amount to politicization of identity [26]. And the more politicized that identities become, the more they display a ferocity, which makes them a force to be reckoned with [27]. The truth is that because of the numerical strength of the neo-Biafran organizations, they are (in funding terms) principally self-sponsored, through the collection of levies that ordinarily would not have amounted to substantial sums of money. Their large memberships however, translate these collections to immense pool of funds. Notably, what the agitators possess that is rare in certain other socio-political jurisdictions is a large measure of accountability. In addition, the neo-Biafran movement has its volunteers in different parts of the globe where the (peripatetic) Igbos reside (including many non-Nigerians from different regions of the planet). The neo-Biafrans in the Diaspora are not strictly members of the two prominent organizations (MASSOB and IPOD). The registered members of these organizations are at home in Nigeria. The non-Nigerian sympathizers are usually attracted by the self-determinism persuasion of the neoBiafran agitation. The agitators derive financial sympathies from these global volunteers.

The central issue in all of this is not an Igbo question. It is relative deprivation and nationbuilding challenges. To adjudicate self-determination disputes beyond the potentially violent zerosum logic of secession [28] the imperatives in the postcolony squarely borders on nation-building determination and the reduction of palpable instances of relative deprivation. The neo-Biafran movement in Nigeria is predominantly driven by relative deprivation. The identity political component of the agitations are functions of relative deprivation. However, the overall compelling issues squarely border on nation-building complications in the postcolony.The supreme task of statesmen in Nigeria should accordingly be nation-building.

\section{References}

[1] Election Monitor (2015). 2015 General Elections Observation Report. Available at: https://app.box.com/s/zy307h3uxmswaeo83mtuc7wqcd6conf2.

[2] Premium Times (2015b). Nigerian government reacts to Biafra, says protest "completely legitimate".http://www.premiumtimesng.com/news/headlines/194638-nigerian-government-reactsto-biafra-says-protest-completely-legitimate.html.

[3] Camara, S. (2015). Nigerians expelled from Senegal stadium for displaying Biafra flags.http://www.premiumtimesng.com/news/top-news/194621-nigerians-expelled-from-senegalstadium-for-displaying-biafra-flags.html

[4] Ibrahim, J. (2015). Resolving the Igbo Question.

http://blogs.premiumtimesng.com/?p=169859. 
[5] Fahey, T. (2010). Poverty and the two concepts of relative deprivation. UCD School of Applied Social Science Working Paper Series WP10/1.

[6] Stouffer, S.A., et al (1949a). The American Soldier: Adjustment during Army Life, Vol.I. Studies in Social Psychology in World War II. Princeton: Princeton University Press.

[7] Stouffer, S.A., et al (1949b). The American Soldier: Combat and Its Aftermath, Vol. II. Studies in Social Psychology in World War II. Princeton: Princeton University Press.

[8] Walker, I., \& Pettigrew, T. F. (1984). Relative deprivation theory: An overview and conceptual critique. British Journal of Social Psychology, 23(4), 301-310.

[9] Kuo, A., \& Margalit, Y. (2012). Measuring Individual Identity: Experimental Evidence. Comparative Politics, 44(4), 459-479.

[10] Odumegwu-Ojukwu, C. (2009). Address at the Professor Chinua Achebe International Colloquium on free and fair Elections in Nigeria at Providence, Rhode Island, 11th December

[11] Lumun, A.N. (2012). Factors for Nation Building and Development in Nigeria. Journal of Social Science and Public Policy. 4(-): 54-59.

[12] Eme, O.I and Onyishi, T. O. (2014). Federalism and Nation Building in Nigeria. Arabian Journal of Business and Management Review (Nigerian Chapter). 2(6): 1-14..

[13] Fagbemi, A, and Tsokar, K, Oliomogbe, H and Udeajah, G. (2015). Muslim leaders urge caution over pro-Biafra violence. http://www.ngrguardiannews.com/2015/12/muslim-leaders-urgecaution-over-pro-biafra-violence/.

[14] Premium Times (2015a). Buhari in Washington ahead of meeting with Obama.

http://www.premiumtimesng.com/news/top-news/186972-buhari-in-washington-ahead-of-meetingwith-obama.html

[15] Mr. Okafor Mathew (informal communication), Unemployed Citizen, 52, July 21, 2015.

[16] Musawa, H. (2015). Legal Possibility of the Federal Republic of Biafra, By Hannatu Musawa http://blogs.premiumtimesng.com/?p=169685\&.

[17] Ibeanu, O. (2015). Resolving the Igbo Non-Question: Pitfalls of Jibo's Single Strand

Ethnic Narrative. http://blogs.premiumtimesng.com/?p=169904\&

[18] Ademoyo, A. (2015). Biafran Secessionist Call: A National Not an Igbo, Question. http://blogs.premiumtimesng.com/?p=169910.

[19] Musawa, H. (2015). Solving the Biafra Agitation Problem.

http://saharareporters.com/2015/11/17/solving-biafra-agitation-problem-hannatu-musawa.

[20] Gurr, T. R. (1970). Why Men Rebel. Princeton, NJ: Princeton University Press.

[21] Ojieh, C. (2015). Popular Diplomacy in an Autocracy-Public Opinion and Foreign Policy Decision-Making under the Military in Nigeria. Ufahamu: A Journal of African Studies, 38(2): 2954.

[22] Ejoh, E. (2015). Nigeria earned \$293bn royalty from oil and gas companies in 7 yrsNEITI.http://www.vanguardngr.com/2015/12/nigeria-earned-293bn-royalty-from-oil-and-gascompanies-in-7-yrs-neiti/

[23] Nwabughiogu, L. (2015). Over 100m Nigerians living below poverty line - Osinbajo. http://www.vanguardngr.com/2015/08/over-1-million-nigerians-living-below-poverty-line-osinbajo/

[24] Adesina, D. (2015). One country, two failures.

http://www.ngrguardiannews.com/2015/12/one-country-two-failures/. 
[25] Premium Times . (2015). Arms Scandal: Jonathan's govt spent billions, abused trust Buhari. http://www.premiumtimesng.com/news/headlines/194920-arms-scandal-jonathans-govtspent-billions-abused-trust-buhari.html.

[26] Ogala, E. (2015). Investigation: Jonathan, Alison-Madueke, Tunde Ayeni, named in fraudulent oil contracts that cost Nigeria billions.

http://www.premiumtimesng.com/investigationspecial-reports/190179-investigation-jonathanalison-madueke-tunde-ayeni-named-in-fraudulent-oil-contracts-that-cost-nigeria-billions.html

[27] Saleh, A. (2013). Relative Deprivation Theory, Nationalism, Ethnicity and Identity Conflicts. Geopolitics Quarterly, 8(4): 156-174.

[28] Simpson, B. (2014). The Biafran secession and the limits of self-determination. Journal of Genocide Research. 16 (2-3): 337-354. 